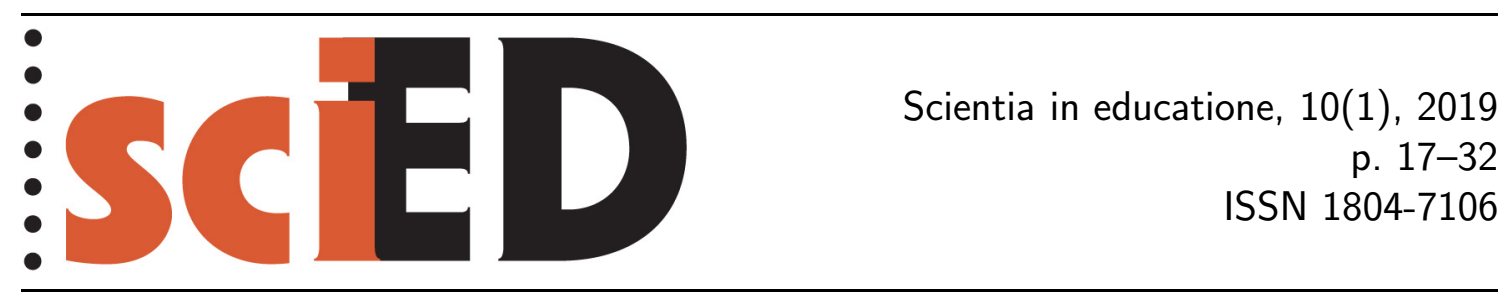

\title{
Hodnotenie v prírodovedných predmetoch v podmienkach slovenského školstva
}

\author{
Renáta Orosová, Mária Ganajová, \\ Katarína Szarka, Mária Babinčáková
}

\begin{abstract}
Abstrakt
Hodnotenie má výrazný vplyv na osobnosť žiaka, na proces jeho učenia sa a v konečnom dôsledku i na vytváranie jeho vztahu k obsahu vyučovacieho predmetu. Národná správa PISA 2015 (NÚCEM, 2017) poukazuje na pokles výkonu žiakov v prírodovednej gramotnosti, pričom najväčšou rizikovou skupinou žiakov sú práve žiaci základných škôl a stredných odborných škôl bez maturity. Pred pedagógmi tak stojí otázka, ako tento stav pozitívne ovplyvnit. Jednou z možností sa javí, na základe mnohých výskumov, formatívne hodnotenie, ktoré má kvalitatívny charakter. Autorky príspevku sa zamerali na zistenie aktuálneho stavu využívania nástrojov hodnotenia vo vyučovaní prírodovedných predmetov. Ako metódu kvantitatívneho výskumu využili dotazník. Príspevok prezentuje čiastkové výsledky výskumu, ktoré poukazujú na značnú prevahu využívania nástrojov sumatívneho hodnotenia nad nástrojmi formatívneho hodnotenia. Respondentmi boli učitelia prírodovedných predmetov základných a stredných škôl na Slovensku.
\end{abstract}

Klúčové slová: hodnotenie, formatívne hodnotenie, nástroje formatívneho hodnotenia, nástroje sumatívneho hodnotenia, sumatívne hodnotenie.

\section{Evaluation in natural science subjects in the current context of Slovak education}

\begin{abstract}
Evaluation has a considerable influence on the personality of the pupil, on his or her learniong process and ultimately also on creating his/her relationship to the content of a school subject. The PISA 2015 National Administration (NUCEM, 2017) indicates a drop in the performance of pupils in natural science literacy, with the largest risk group of pupils being pupils of primary schools and secondary vocational schools without baccalaureate. The question facing the educators is how to reverse this negative trend. On the basis of substantial research one of the options appears to be a formative assessment which has a qualitative character. The authors of the paper sought to establish the current status of evaluation tools in the teaching of natural science subjects. They used the questionnaire as a method of quantitative research. The paper presents partial research findings that point to the considerable dominance of using tools of summative assessment over tools of formative assessment. The respondents were teachers of natural science subjects in primary and secondary schools in Slovakia.
\end{abstract}

Key words: evaluation, formative assessment, tools of formative assessment, tools of summative assessment, summative assessment. 
V každej oblasti l’udského života sa stretávame s hodnotením. V súčasnej spoločnosti sa hodnotenie stáva diskutovanou témou, predovšetkým vo vztahu ku kvalite. Zamestnávatelia hodnotia svojich zamestnancov, zákazníci zase poskytovatelov služieb a pod. Každý z nás sa dostáva počas svojho života tak do pozície hodnotitela, ako i hodnoteného. Hodnoteniu je venovaná pozornoste na národných, celonárodných i medzinárodných úrovniach. Sú realizované štúdie rôzneho zamerania smerujúce k hodnoteniu vybraných oblastí. Jednou z oblastí neustáleho procesu hodnotenia je školstvo. V ostatnej dobe bola zverejnená Národná správa PISA 2015 (NÚCEM, 2017), ktorá poukazuje na pokles výkonu žiakov v prírodovednej gramotnosti, pričom najväčšou rizikovou skupinou žiakov sú žiaci základných škôl a stredných odborných škôl bez maturity. Odborná verejnost’ pristupuje k diskusiám, čo je príčinou poklesu výkonov žiakov v prírodovednej gramotnosti a ako tento nežiadúci stav zmeniṫ. Hlbším zamyslením sa nad týmto stavom je možné naznačit vzájomné súvislosti medzi motiváciou žiakov $\mathrm{k}$ učeniu sa $\mathrm{v}$ prírodovedných predmetoch a následnými nadobudnutými znalostami (prírodovednou gramotnostou). Jednou z možností zvýšenia motivácie žiakov sa javí práve školské hodnotenie, ktoré má výrazný vplyv na osobnost žiaka, na proces jeho učenia sa a na vytváranie vzţahu k samotnému predmetu i obsahu vyučovacieho predmetu.

\section{1 ŠKOLSKÉ HODNOTENIE}

Problémy spojené so školským hodnotením nie sú novodobými fenoménmi. John Holt v 60. rokoch 20. storočia už upozornil na to, že použité hodnotiace metódy nie sú vhodné na skúmanie a odhalenie skutočných vedomostí žiakov. Podla neho školský proces pod heslom „hodnotenie“ je spoločným klamstvom učitelov, žiakov a rodičov. Zdôrazňuje, že výsledky klasifikácie neodzrkadlujú skutočný poznatok žiakov, napriek tomu si učitelia zvolia takúto cestu interpretácie dát učebných výsledkov. Tradičné hodnotenie preferujúce sumatívne hodnotenie prispelo k tomu, aby sa vedomosti reálneho života vzdialili od školských vedomostí. Totiž žiaci neuplatnia svoje školské poznatky v reálnych situáciách, ved’ školské vedomosti sú pre nich iba na to, aby získali známky (Holt, 1991). Naopak hodnotenie by malo prispiet k motivácii žiaka učit sa, odhalené chyby opravit, nedostatky sa doučit a postupovat $\mathrm{v}$ procese progresu.

Pedagogické hodnotenie chápeme v úzkom slova zmysle v spojení so vzdelávacou činnostou, pričom dochádza k posúdeniu úrovne stavu hodnoteného subjektu (žiak, učitel' a ich kompetencie: vedomosti, zručnosti, návyky a postoje) s vopred vytýčenými cielmi. Pri hodnotení dochádza k prepojeniu ciela, procesu a konečného stavu vzdelávania. Ked’ sa analyzuje pojem anglického podstatného mena „assessment“ hodnotenie, odvodeného zo slovesa „assess“ - hodnotit, ktoré pochádza z lat. slova „assidere“, pochopíme jeho ozajstný konceptuálny význam (Szarka, 2017). Slovo „assidere" v angl. význame „to sit with" (sediet s niekým), resp. „to sit beside“ (sediet vedla niekoho), môžeme v kontexte školského hodnotenia chápat̉ ako pomoc/usmernenie učiaceho sa, teda pracujeme so študentom na jeho uvedomení si vlastných výsledkov vyučovacieho procesu.

Školské hodnotenie tvorí neodmyslitelnú súčast’ vyučovacieho procesu. Kolář a Šikulová (2009: s. 16) považujú hodnotenie za „prostriedok riadenia, ovplyvňovania a usmerňovania učebných činností žiakov“. Kalhous a Obst (2002) definujú školské hodnotenie ako zistenie kompetencií (vedomostí, zručností a postojov) žiaka a formuláciu hodnotiacich súdov na základe porovnávania skutočného stavu so stavom 
predpokladaným, formulovaným ako ciel’ výučby. Čapek (2015) považuje za školské hodnotenie všetko, čo sa deje v školskej triede: učitel' hodnotí žiakov, žiaci sa hodnotia navzájom, hodnotia sami seba, ba dokonca hodnotia i učitela. Zmyslom školského hodnotenia je, aby sme naučili žiaka kriticky mysliet, pravdivo a spravodlivo vyjadrovat svoje myšlienky, objektívne hodnotit a podporovat pozitívne medziludské vztahy. Školské hodnotenie je súčastou pedagogickej činnosti učitelov, no výskumy ukazujú, že učitelia na druhom stupni základných škôl považujú hodnotenie žiakov za jednu z piatich najtažších zložiek pedagogickej činnosti (Bendel, in Průcha, 1997) a zároveň štvrtú najtažšiu činnost’ začínajúcich učitelov (Veenman, in Průcha, 1997). Hodnotenie je cielavedomá činnost'. Kyriacou (2012: s. 121-123) uvádza šest základných cielov hodnotenia. Hodnotenie má byt̉ spätnou väzbou pre učitel’a o prospechu žiaka, má poskytovat žiakom spätnú väzbu o ich pokroku, motivovat žiakov, byt podkladom pre vedenie záznamov o prospechu žiaka, poskytovat doklady o dosiahnutej úrovni žiaka a posúdit pripravenosť žiaka pre dalšie učenie. Hlavným „zmyslom hodnotenia žiaka je, aby sa naučil hodnotit svet, ale predovšetkým sám seba“ (Kosová, 2000: s. 20).

\section{Formatívne hodnotenie}

V 60. a 70. rokoch minulého storočia sa v západných krajinách objavili nové náhlady na hodnotenie vzdelávania, išlo o sumatívne a formatívne hodnotenie s rozlíšením formy a metódy hodnotenia na základe účelu. Kým cielom sumatívneho hodnotenia bolo nasadenie preverovacieho prostriedku vždy na konci aktivity, celku, obdobia a pod. a bolo spojené s klasifikáciou, cielom formatívneho hodnotenia sa stala spätná väzba, získanie informácií ako sa žiaci učia a diagnostikovanie nedostatkov, tá však mala v našich podmienkach formálny charakter a bola spájaná iba so slovným „komentárom" učitela k výsledku (Turek, 2014).

Scriven (1967) ako prvý navrhol rozlišovat medzi sumatívnymi a formatívnymi prístupmi. Vyzval učitelov, aby získavali informácie k identifikácii oblastí, ktoré je potrebné zlepšit v učení žiakov. Od 90. rokov došlo k prudkému nárastu záujmu o formatívne hodnotenie. P. Black a D. Wiliam v dielach Assessment and classroom learning (1998) a Inside the Black Box (1998) vysvetlili termín formatívne hodnotenie a zdôraznili jeho pozitívny vplyv na učenie žiakov. Autori dospeli k záveru, že formatívne hodnotenie zlepšuje výkony najmä slabších žiakov. Práve podpora slabších žiakov vedie k odstráneniu medzier medzi výkonne nadpriemernými a podpriemernými žiakmi.

Výskumy v zahraničí ukazujú, že formatívne hodnotenie zlepšuje výsledky žiakov, zlepšuje pracovnú klímu v triede a žiaci začínajú prijímat hodnotenie ako prirodzenú súčast’ života (Grob, Holmeier \& Labudde, 2017; Januševa \& Jurukovska, 2017; Earle, 2014).

Expertná skupina pre reformu hodnotenia vo Velkej Británii (Assessment Reform Group) ako nasledovníci Blacka a Wiliama pri zásadných zmenách paradigiem školského hodnotenia mali za zásluhu aj zavedenie novej terminológie. Spomínaná skupina expertov začala prvýkrát používat namiesto pojmu sumatívne hodnotenie pojem assessment of learning, čo môžeme koncipovat’ v slovenskom jazyku ako hodnotenie učenia sa, hodnotenie výsledkov učenia sa, hodnotenie výkonu učenia sa atd', a namiesto pojmu formatívne hodnotenie, pojem assessment for learning. V slovenskom preklade je to hodnotenie pre učenie sa, hodnotenie podporujúce učenie sa, avšak formulácia rozvíjajúce hodnotenie ovela viac zachytáva podstatu významu 
pojmu, čo sa týka hodnotenia progresu a rozvoja žiaka v učebnom procese, čo pochopíme až v rozširujúcom kontexte školského hodnotenia koncepcie „assessment as learning“ (AasL) - hodnotenia ako formy učenia sa (Earl \& Katz, 2006).

Pri formatívnom hodnotení ide teda predovšetkým o pozitívny rozvoj žiaka v oblasti poznania a správania sa. Cielom formatívneho hodnotenia je priniest́ informáciu o aktuálnom stave vedomostí a zručností žiakov a nasmerovat ich k uvedomeniu si nedostatkov a $\mathrm{k}$ ich efektívnej eliminácii. Pri formatívnom hodnotení nie je využívaná klasifikácia, bodové hodnotenie, percentuálne hodnotenie a pod. Základom je informácia. Informácia o možnostiach pokroku žiaka v procese učenia sa. Pri formatívnom hodnotení sa využíva predovšetkým verbálne hodnotenie (Starý \& Laufková, et al., 2016: s. 16). Hodnotia sa prejavy učenia tak blížiace sa k dokonalosti, ako i tie, ktoré majú od dokonalosti vel’mi d’aleko. Je však dôležité, aby učitel' vedel s chybou správne pracovat. Formatívne hodnotenie umožňuje učitelovi a žiakovi aktívne spolupracovat a ovplyvňovat proces hodnotiacej činnosti. Výmena názorov medzi učitelom a žiakom, medzi žiakmi navzájom, by mala byt’ hermeneutická, kedy sa každý zo zúčastnených snaží pochopit odkaz toho druhého. Vplyvom formatívneho hodnotenia by mal byt žiak schopný urobit to, čo sa mu predtým nepodarilo a potreboval pomoc učitela. Mnohí autori tak vnímajú formatívne hodnotenie nielen ako hodnotiaci proces, ale i vyučovací proces (Black \& Wiliam, 2003; Torrance \& Pryor, 2001). Ide o cyklus, pri ktorom sa žiaci v škole viac naučia, budú chodit do školy s radostou, v triede bude lepšia pracovná klíma, žiaci sa budú cítit lepšie a rodičia sa viac dozvedia o priebehu školského vzdelávania a svoju pomoc budú môct’ adresnejšie podporovat (obr. 1).

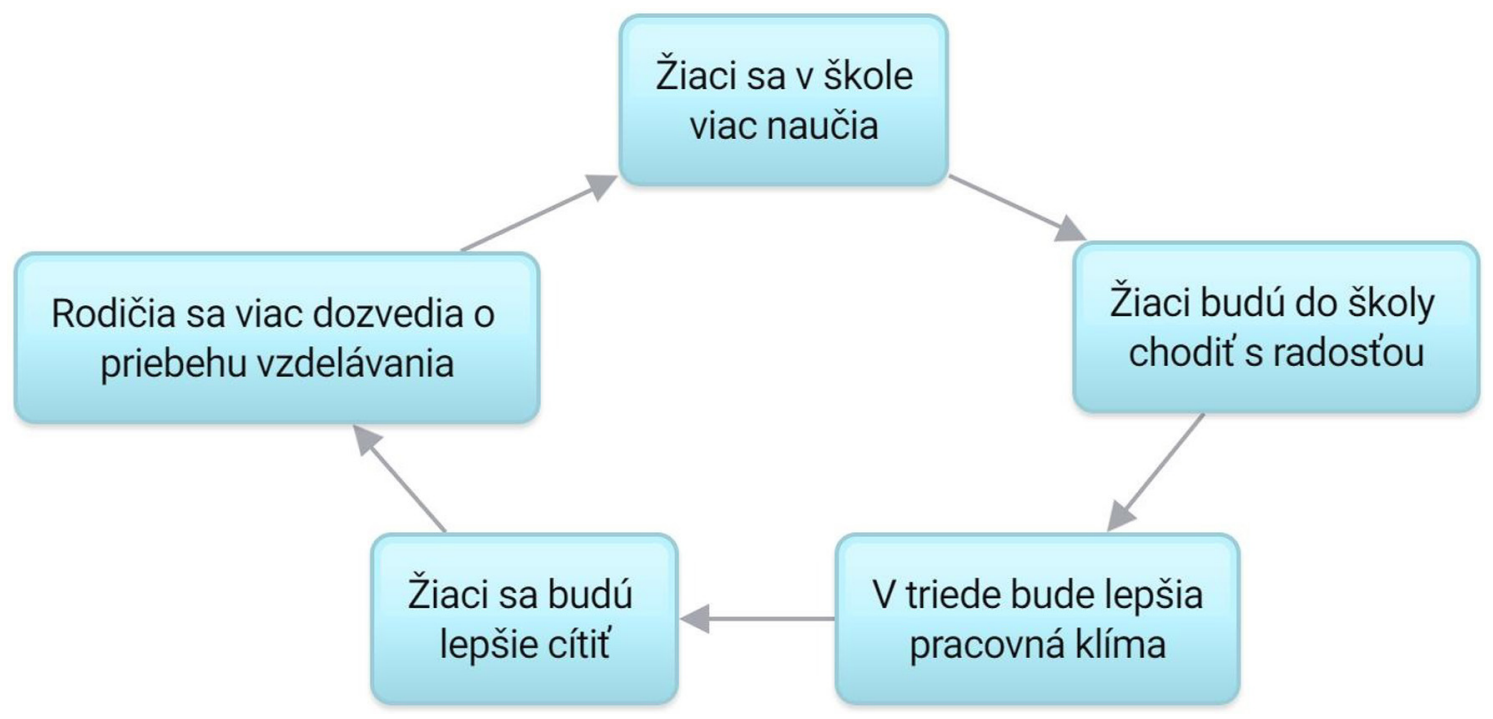

Obr. 1: Prečo používat formatívne hodnotenie (zdroj: Starý \& Laufková, et al., 2016)

\subsection{NÁstroje FORMATÍVNEHO HODNOTENIA}

Metóda je vo všeobecnosti uvedomelý a cielavedomý postup, určitým spôsobom usporiadaná činnoste, ktorá má vieste k splneniu vytýčeného ciela. Pri formatívnom hodnotení je potrebné si uvedomit, že toto hodnotenie vychádza z autonómneho hodnotenia, kedy žiaci sú vlastníci svojho učenia. Starý a Laufková, et al. (2016: s. 28) rozlišujú tri základné metódy formatívneho hodnotenia: vrstovnícke hodnotenie, sebahodnotenie a hodnotenie učitelom. Technikami formatívneho hodnotenia 
označujú „postupy, ktorými je naplánovaná určitá metóda - napr. technika semafora, žiadne ruky hore a pod." (Starý \& Laufková, et al., 2016: s. 26). Konkrétne produkty formatívneho hodnotenia, napr. portfólio žiaka, žiacky diár a pod., považujú za nástroje formatívneho hodnotenia.

K najznámejším nástrojom formatívneho hodnotenia môžeme zaradit sebahodnotiace listy, sebahodnotiace karty, metakogníciu, lístok pri odchode, pojmové mapy, sumár a portfólio.

Sebahodnotiace listy slúžia k sformalizovaniu záznamov o cieloch, priebežnej práci a dosiahnutých výsledkoch. Žiaci sa učia sformulovat svoje myšlienky písomne. Sebahodnotiace listy môžu mat niekolko podôb. Môže íst' o otázky (napr. „Čo sa podarilo?"), o nedokončené vety (napr. „Dnes som sa naučil/a... “) alebo navádzajúce otázky, ktoré obsahujú kritériá hodnotenia (napr. „Kolkko chýb si urobil/a v domácej úlohe?"; Mešková, 2012).

Sebahodnotiace karty slúžia na rozvíjanie kompetencie rozmýšlania o vlastnom spôsobe učenia sa a zabezpečenie snahy celoživotného vzdelávania sa u žiakov. Žiak vyjadruje svoje hodnotenie zaradením do príslušnej kategórie (napr. „viem opísat’... samostatne, s menšou pomocou učitela, s výdatnou pomocou učitela").

Metakognícia ako schopnost žiakov analyzovat vlastné učenie sa a toto učenie efektívne riadit (Flavell, 1979). Metakognícia sa prejavuje tým, že si žiak kladie otázky súvisiace s textom a ak na jednotlivé otázky nedokáže odpovedat musí sa rozhodnút akú stratégiu učenia využije, aby svoj kognitívny ciel’ dosiahol. Môže si napríklad spomínaný text prečítat znova a hladat pri tom odpovede na vopred položené otázky, prostredníctvom ktorých danému textu porozumie.

Lístok pri odchode je nástrojom formatívneho hodnotenia, pri ktorom žiaci odovzdávajú pri odchode z triedy vyplnený lístok. Uvádzajú v ňom 3 poznatky, zručnosti, ktoré sa dnes naučili, 2 aktivity, informácie, ktoré ich najviac zaujali a 1 otázku, ktorú majú stále nezodpovedanú. Učitel’ tak má možnost získat spätnú väzbu a na nezodpovedané otázky žiakov môže odpovedat́ na nasledujúcej hodine.

Pojmové mapy sa používajú ako efektívny nástroj na porozumenie rozsiahlejších tém (tematických celkov). Jedná sa o grafické zobrazenie klúčových pojmov, prvkov, vlastností, procesov a väzieb medzi nimi. Žiaci pojmové mapy vytvárajú v závere tematického celku ako vyjadrenie ich osobného porozumenia súvislosti, väzieb a fungovania daného systému. Tento nástroj dáva spätnú väzbu aj žiakovi, pretože dokáže opísat hlavné časti a súvislosti v danej problematike.

Sumár sa realizuje po výučbe s cielom kontroly porozumenia a zistenia, čo na hodine žiaci robili a čo sa naučili. Pri volbe dĺžky sumára musíme prihliadat́ na vekovú skupinu žiakov, ale aj na to, kolko informácii chceme od žiakov získat a aké majú byt tieto informácie podrobné. Rozdielna dľžka slov vyžaduje rozdielnu pozornost’ pre detaily.

Portfólio predstavuje súbor produktov, ktoré žiak vytvoril, a obsahuje d’alšie záznamy o žiakovi vytvorené pre účely hodnotenia. Poskytuje informáciu a prehlad o žiakovi ako sa učí, ako uvažuje, vyrába predmety. Predstavuje najucelenejší pohlad na osobnost žiaka.

V celom procese hodnotenia je dôležité si uvedomit, že stredobodom je žiak. Motivovaný žiak má záujem o proces učenia, vidí zmysel nadobudnutých vedomostí pre svoju činnost a život a predovšetkým sa motivovaný žiak učí pre vedomost̉ a nie pre dobrú známku. Pre neho hodnotenie, posudzovací charakter hodnotenia nie je podstatné, avšak kontinuálna a konzekventná spätná väzba je nutná podmienka k jeho pokroku. Základnú dilému súčasného školského hodnotenia by sme vedeli formulovat v štyroch otázkach: (a) Či sa naozaj hodnotia u mladej generácie v rámci výchovno- 
-vzdelávacieho procesu poznatky potrebné pre ich život v znalostnej spoločnosti?, (b) Či doposial' používané nástroje hodnotenia sú vhodné a postačujúce na monitorovanie a hodnotenie procesu učenia sa žiakov v informačno-znalostnej spoločnosti?, (c) Majú učitelia dostatočné znalosti z oblasti vzdelávacieho procesu a zručnosti implementovania hodnotenia do odborno-didaktických kontextov?, (d) Sú nové koncepcie a stratégie školského hodnotenia súčastou študijných programov vzdelávania budúcich učitelov? (Szarka, 2017).

\section{Ciel' vÝsKumu}

Základné dilémy spomenuté vo vyššie uvedených otázkach nás viedli $\mathrm{k}$ hlbšiemu skúmaniu súčasného hodnotenia $\mathrm{v}$ podmienkach výučby prírodovedných predmetov, učitelmi využívaných nástrojov hodnotenia vo výučbe a ich názorov a postojov $\mathrm{k}$ hodnoteniu v pedagogickej praxi.

Hlavným cielom výskumu bolo zistit’ a zhodnotit využívanie formatívneho hodnotenia v pedagogickej praxi učitel'ov prírodovedných predmetov.

Na základe uvedeného ciela boli sformulované výskumné otázky, z ktorých pre potreby tejto štúdie uvádzame nasledovné:

VO1: Do akej miery sú využívané nástroje formatívneho a sumatívneho hodnotenia vo vyučovaní prírodovedných predmetov?

VO2: Existuje vztah medzi vybranými socio-demografickými premennými (dížka pedagogickej praxe, typ školy, aprobačný predmet) a premennými týkajúcimi sa formatívneho a sumatívneho hodnotenia (miera využívania nástrojov formatívneho a sumatívneho hodnotenia)?

Pod pojmom miera používania rozumieme frekvenciu (ako často), akou respondent (učitel') vo vyučovacom procese využíva prezentované nástroje hodnotenia.

\section{Metodológia VÝSKUmu}

\section{VÝSKUMNÁ VZORKA}

Výberový výskumný súbor tvorilo $N=81$ respondentov, t.j. učitelov základných a stredných škôl chémie v kombinácii, z toho 7,4 \% tvorili muži $(N=6)$ a $92,6 \%$ ženy $(N=75)$. Na výskume participovali učitelia chémie, ktorí ako druhý aprobačný predmet mali biológiu $(N=26 ; 32,1 \%)$, matematiku $(N=19 ; 23,5 \%)$, fyziku $(N=8 ; 9,9 \%)$, geografiu $(N=3 ; 3,7 \%)$ a informatiku $(N=2 ; 2,5 \%)$. Na výskume sa zúčastnili i učitelia, ktorí vyučovali iba predmet chémia $(N=23$; 28,4 \%). Najväčšie zastúpenie mali učitelia s aprobáciou chémia - biológia (tab. 1).

Respondenti boli z troch krajov: Bratislavského kraja $(N=20 ; 24,7 \%)$, Banskobystrického kraja $(N=26 ; 32,1 \%)$ a Košického kraja $(N=35 ; 43,2 \%)$ a pôsobia na základných školách $(N=65 ; 81,3 \%)$ a stredných školách $(N=15 ; 18,8 \%)$. Jeden respondent neuviedol svoje pôsobisko.

Pedagogická prax respondentov sa pohybovala najčastejšie v rozmedzí 16-20 rokov $(N=20 ; 24,7 \%)$. Rovnaké rozloženie respondentov nastalo v kategóriách 11-15 rokov, 21-25 rokov a nad 31 rokov (pre každú kategóriu $N=13 ; 16,0 \%$ ). Najnižšie zastúpenie mali učitelia s pedagogickou praxou do $5 \operatorname{rokov}(N=4 ; 4,9 \%)$. 
Tab. 1: Výskumná vzorka

\begin{tabular}{l|l|r|r}
\hline \multicolumn{2}{l|}{ Socio-demografická premenná } & $N$ & $\%$ \\
\hline Pohlavie & muž & 6 & 7,4 \\
\hline & žena & 75 & 92,6 \\
\hline Aprobačný predmet & matematika & 19 & 23,5 \\
\hline & biológia & 26 & 32,1 \\
\hline & fyzika & 8 & 9,9 \\
\hline & geografia & 3 & 3,7 \\
\hline & chémia & 23 & 28,4 \\
\hline & informatika & 2 & 2,5 \\
\hline Typ školy & ZŚ & 65 & 80,2 \\
\hline & SŚ & 15 & 18,5 \\
\hline & neuvedené & 1 & 1,2 \\
\hline Kraj & BA & 20 & 24,7 \\
\hline & BB & 26 & 32,1 \\
\hline & KE & 35 & 43,2 \\
\hline Dĺžka pedagogickej praxe & $0-5$ rokov & 4 & 4,9 \\
\hline & $6-10$ rokov & 9 & 11,1 \\
\hline & $11-15$ rokov & 13 & 16,0 \\
\hline & $16-20$ rokov & 20 & 24,7 \\
\hline & $21-25$ rokov & 13 & 16,0 \\
\hline & $26-30$ rokov & 9 & 11,1 \\
\hline & nad 31 rokov & 13 & 16,0 \\
\hline
\end{tabular}

Zdroj: vlastné spracovanie

\section{METODIKA VÝSKUMU}

Výskum prebiehal v školskom roku 2017/2018. Oslovení boli účastníci školení pre učitelov chémie v jednotlivých krajských mestách. Ako výskumný nástroj bol použitý škálový dotazník. Dotazník obsahoval 3 moduly. V prvom module A boli základné informácie o respondentoch. $\mathrm{V}$ moduloch $\mathrm{B}$ a $\mathrm{C}$ respondenti hodnotili výroky týkajúce sa aktivizujúcich metód výučby a hodnotenia výsledkov žiakov pomocou pätstupňovej Likertovej škály A ( $5=$ rozhodne nesúhlasím, $4=$ nesúhlasím, $3=$ neviem, $2=$ súhlasím, $1=$ rozhodne súhlasím) alebo Likertovej škály B ( $5=$ vždy, $4=$ často, $3=$ niekedy, $2=$ málokedy, $1=$ nikdy). Reliabilita jednotlivých subškál modulov bola dostatočná, Cronbachove alpha pre subškálu nástroje formatívneho a sumatívneho hodnotenia je $\alpha=0,815$.

\section{ANALÝZA DÁT}

Pri spracovaní získaných údajov sme využívali nástroje javovej analýzy, popisnej štatistiky (priemer, modus, smerodajná odchýlka, špicatoste, šikmoste, rozpätie, maximum, minimum, súčet, median) a induktívnej štatistiky (Kolmogorov-Smirnov test na posúdenie normality rozloženia dát, neparametrický Wilcoxonov test porovnanie miery využitia nástrojov formatívneho a sumatívneho hodnotenia a Chí-kvadrát na analýzu rozdelenia početnosti). Analýza údajov bola vykonaná pomocou štatistického programu IBM SPSS Statistics 20. 


\section{VÝSLEDKY VÝSKUMU}

Pre potreby tejto štúdie sme spracovali výsledky týkajúce sa nástrojov formatívneho a sumatívneho hodnotenia. Získané dáta podrobené Kolmogorov-Smirnovmu testu normality rozloženia dát vykazovali $p<0,05$, preto sme následne pri štatistickom spracovaní a komparácií dát využívali neparametrické testy.

Tab. 2: Kolmogorov-Smirnov test normality rozloženia dát

\begin{tabular}{|c|c|c|c|c|c|}
\hline & \multirow{2}{*}{$N$} & \multicolumn{2}{|c|}{ Normal Parameters ${ }^{\mathrm{a}, \mathrm{b}}$} & \multirow{2}{*}{$\begin{array}{l}\text { Kolmogorov- } \\
\text {-Smirnov Z }\end{array}$} & \multirow{2}{*}{$\begin{array}{l}\text { (2-tailed) } \\
\text { (2-tailed) }\end{array}$} \\
\hline & & Mean & Std. Deviation & & \\
\hline \multicolumn{6}{|l|}{$\begin{array}{l}\text { Nástroje sumatívneho } \\
\text { hodnotenia }\end{array}$} \\
\hline $\begin{array}{l}\text { Krátke písomné previerky, } \\
\text { tzv. bleskovky }\end{array}$ & 81 & 3,38 &, 874 & 2,617 &, 000 \\
\hline Slovné odpovede & 78 & 3,71 &, 884 & 2,399 &, 000 \\
\hline $\begin{array}{l}\text { Domáce úlohy } \\
\text { a samostatné úlohy }\end{array}$ & 81 & 3,40 &, 904 & 1,910 &, 001 \\
\hline Referát & 80 & 2,88 &, 663 & 3,128 &, 000 \\
\hline Testy & 78 & 3,81 &, 757 & 2,584 &, 000 \\
\hline $\begin{array}{l}\text { Výstupy laboratórnych } \\
\text { prác }\end{array}$ & 79 & 3,85 & 1,051 & 2,030 &, 001 \\
\hline $\begin{array}{l}\text { Výstupy projektových } \\
\text { prác }\end{array}$ & 75 & 3,39 & 1,138 & 1,556 &, 016 \\
\hline \multicolumn{6}{|l|}{$\begin{array}{l}\text { Nástroje formatívneho } \\
\text { hodnotenia }\end{array}$} \\
\hline Metakognícia & 60 & 2,48 & 1,049 & 1,591 & ,013 \\
\hline Sumár & 68 & 2,93 & 1,150 & 1,787 & ,003 \\
\hline Lístok pri odchode & 66 & 1,48 &, 827 & 3,150 &, 000 \\
\hline $\begin{array}{l}\text { Konceptuálne/pojmové } \\
\text { mapy }\end{array}$ & 76 & 2,67 & ,999 & 1,814 & ,003 \\
\hline $\begin{array}{l}\text { Sebahodnotiaca karta } \\
\text { žiaka }\end{array}$ & 74 & 2,14 & 1,220 & 2,205 &, 000 \\
\hline $\begin{array}{l}\text { Vzájomné hodnotenie } \\
\text { žiakov }\end{array}$ & 78 & 3,33 & 1,002 & 2,069 &, 000 \\
\hline $\begin{array}{l}\text { Dotazník/spätná väzba } \\
\text { spokojnosti }\end{array}$ & 77 & 2,29 & 1,134 & 1,614 &, 011 \\
\hline $\begin{array}{l}\text { Hodnotenie skupinovej } \\
\text { práce }\end{array}$ & 79 & 3,20 &, 979 & 2,022 & ,001 \\
\hline $\begin{array}{l}\text { Vzájomné hodnotenie } \\
\text { žiakov v skupine }\end{array}$ & 79 & 2,89 & 1,013 & 2,142 &, 000 \\
\hline $\begin{array}{l}\text { Sebareflexia žiaka } \\
\text { v skupinovej práci }\end{array}$ & 77 & 2,83 & 1,069 & 1,633 & ,010 \\
\hline Žiacke Portfólio & 73 & 2,16 & 1,323 & 2,127 & ,000 \\
\hline Žiacke e-portfólio & 67 & 1,61 & 1,167 & 3,408 &, 000 \\
\hline
\end{tabular}

Zdroj: vlastné spracovanie

VO1: Do akej miery sú využivané nástroje formatívneho a sumatívneho hodnotenia vo vyučovaní prírodovedných predmetov? 
Tab. 3: Miera využívania nástrojov sumatívneho hodnotenia

\begin{tabular}{l|c|c|c|c|c|c}
\hline & $\begin{array}{c}\text { nikdy } \\
\%\end{array}$ & $\begin{array}{c}\text { málokedy } \\
\%\end{array}$ & $\begin{array}{c}\text { niekedy } \\
\%\end{array}$ & $\begin{array}{c}\text { často } \\
\%\end{array}$ & $\begin{array}{c}\text { vždy } \\
\%\end{array}$ & $\begin{array}{c}\text { total } \\
\%\end{array}$ \\
\hline $\begin{array}{l}\text { Krátke písomné previerky, } \\
\text { tzv.bleskovky }\end{array}$ & 3,70 & 11,10 & 32,10 & 49,40 & 3,7 & 100,00 \\
Slovné odpovede & 1,30 & 7,70 & 26,90 & 47,40 & 16,70 & 100,00 \\
$\begin{array}{l}\text { Domáce úlohy a samostatné } \\
\text { úlohy }\end{array}$ & 0,00 & 17,30 & 37,00 & 34,60 & 11,10 & 100,00 \\
Referát & 2,50 & 20,00 & 66,30 & 10,00 & 1,30 & 100,00 \\
Testy & 1,30 & 1,30 & 28,20 & 53,80 & 15,40 & 100,00 \\
Výstupy laboratórnych prác & 5,10 & 2,50 & 25,30 & 36,70 & 30,40 & 100,00 \\
Výstupy projektových prác & 5,30 & 16,00 & 33,30 & 25,30 & 20,00 & 100,00 \\
\hline Priemer & 2,74 & 10,84 & 35,59 & 36,74 & 14,09 & 100,00 \\
\hline
\end{tabular}

Zdroj: vlastné spracovanie

Tab. 4: Miera využívania nástrojov formatívneho hodnotenia

\begin{tabular}{l|r|c|r|r|r|c}
\hline & nikdy & málokedy & niekedy & často & \multicolumn{1}{c|}{ vždy } & total \\
\hline & $\%$ & $\%$ & $\%$ & \multicolumn{1}{c}{$\%$} & \multicolumn{1}{c}{$\%$} & $\%$ \\
\hline Metakognícia & 20,00 & 28,30 & 40,00 & 6,70 & 5,00 & 100,00 \\
Sumár & 14,70 & 16,20 & 39,70 & 20,60 & 8,80 & 100,00 \\
Lístok pri odchode & 66,70 & 22,70 & 7,60 & 1,50 & 1,50 & 100,00 \\
Konceptuálne/pojmové mapy & 14,50 & 27,60 & 34,20 & 23,70 & 0,00 & 100,00 \\
Sebahodnotiaca karta žiaka & 43,20 & 20,30 & 20,30 & 12,20 & 4,10 & 100,00 \\
Vzájomné hodnotenie žiakov & 2,60 & 20,50 & 28,20 & 38,50 & 10,30 & 100,00 \\
Dotazník/spätná väzba & 31,20 & 27,30 & 27,30 & 10,40 & 3,90 & 100,00 \\
spokojnosti & & & & & & \\
Hodnotenie skupinovej práce & 3,80 & 17,70 & 43,00 & 25,30 & 10,10 & 100,00 \\
Vzájomné hodnotenie žiakov & 11,40 & 19,00 & 43,00 & 22,80 & 3,80 & 100,00 \\
v skupine & & & & & & \\
Sebareflexia žiaka & 13,00 & 24,70 & 31,20 & 28,60 & 2,60 & 100,00 \\
v skupinovej práci & & & & & & \\
Žiacke Portfólio & 43,80 & 23,30 & 13,70 & 11,00 & 8,20 & 100,00 \\
Žiacke e-portfólio & 71,60 & 11,90 & 6,00 & 4,50 & 6,00 & 100,00 \\
Priemer & 28,04 & 21,63 & 27,85 & 17,15 & 5,36 & 100,00 \\
\hline
\end{tabular}

Zdroj: vlastné spracovanie

Respondenti sa vyjadrovali k uvedeným nástrojom sumatívneho a formatívneho hodnotenia. Pri nástrojoch sumatívneho hodnotenia (tab. 3) sme zistili, že respondenti - učitelia chémie využívajú v prevažnej miere testy $(69,2 \%)$, výstupy laboratórnych prác $(67,1 \%)$, slovné odpovede $(64,1 \%)$ a krátke písomné previerky $(53,1 \%)$. Referát využíva niekedy $66,3 \%$ respondentov. Nikdy a málokedy využíva nástroje sumatívneho hodnotenia 13,59 \% respondentov, kým vždy a často až 50,83\% respondentov. Uvedené nástroje sumatívneho hodnotenia sú najčastejšie využívané vo vyučovacom procese, avšak popri pozitívach (rýchla spätná väzba kvantitatívna), majú mnoho nedostatkov. Najväčším z nich je nekomplexnost̉ hodnotenia výsledkov žiakov týmito nástrojmi.

Respondenti využívajú nástroje formatívneho hodnotenia (tab. 4) vždy, často $(22,51 \%)$, nikdy a málokedy $(49,67 \%)$. V porovnaní s mierou využívania nástrojov 
sumatívneho hodnotenia môžeme na základe popisnej štatistiky konštatovat', že ide presne o obrátený pomer. Vo vyučovaní prírodovedných predmetov respondenti využívajú predovšetkým nástroje sumatívneho hodnotenia. Z nástrojov formatívneho hodnotenia respondenti využívajú v najväčšej miere vzájomné hodnotenie žiakov (48,8 \%) a hodnotenie skupinovej práce $(35,4 \%)$. Nikdy a málokedy využívajú lístok pri odchode (89,4\%), žiacke e-portfólio (83,5 \%), žiacke portfólio $(67,1 \%)$, sebahodnotiacu kartu žiaka (63,5 \%) a dotazník/spätnú väzbu spokojnosti (58,5\%). Nikdy nevyužívajú respondenti žiacke e-portfólio (71,6 \%), lístok pri odchode $(66,7 \%)$, žiacke portfólio $(43,8 \%)$ a sebahodnotiacu kartu žiaka (43,2 \%). Práve tieto nástroje podporujú sebareflexiu žiaka, ponúkajú spätnú väzbu učitelovi zameranú nielen na výsledky vyučovacieho procesu, ale na tak dôležitý priebeh osvojovania si nových poznatkov. Tieto nástroje sú podkladom pre formovanie osobnosti žiaka a jeho vzṫahu $\mathrm{k}$ predmetu.

Vychádzajúc z výsledkov popisnej štatistiky sme sa zamerali na štatistickú verifikáciu hypotézy.

$\mathrm{H}_{0}$ : V miere používania nástrojov sumatívneho a formatívneho hodnotenia nie sú signifikantné rozdiely.

$\mathrm{H}_{1}$ : V miere používania nástrojov sumatívneho a formatívneho hodnotenia sú signifikantné rozdiely.

Na verifikáciu hypotézy sme použili neparametrický Wilcoxonov párový test.

Tab. 5: Wilcoxon Signed Ranks Test

\begin{tabular}{|c|c|c|c|c|c|}
\hline & & & $N$ & $\begin{array}{l}\text { Mean } \\
\text { Rank }\end{array}$ & $\begin{array}{l}\text { Sum of } \\
\text { Ranks }\end{array}$ \\
\hline & & Negative Ranks & 29 & 25,86 & 750,00 \\
\hline & & Positive Ranks & 13 & 11,77 & 153,00 \\
\hline sumativne techniky - & ormativne techniky & Ties & 1 & & \\
\hline & & Total & 43 & & \\
\hline & Test Statistics & & & & \\
\hline & sumatívne technik & - formatívne tec & $\overline{\text { niky }}$ & & \\
\hline$\overline{\mathrm{Z}}$ & & & $\overline{3,738}$ & & \\
\hline Asymp. Sig. (2-tailed) & & &, 000 & & \\
\hline
\end{tabular}

Zdroj: vlastné spracovanie

Štatistické testovanie na hladine významnosti $\alpha=0,05$ ukázalo, že existuje štatisticky významný rozdiel v miere používania nástrojov sumatívneho a formatívneho hodnotenia (tab. 5).

VO2: Existuje vztah medzi vybranými socio-demografickými premennými (kraj, typ školy, dľ̌ka pedagogickej praxe, aprobačný predmet) a premennými týkajúcimi sa formatívneho a sumatívneho hodnotenia (miera využivania nástrojov formatívneho a sumativneho hodnotenia)?

Nástroje sumatívneho a formatívneho hodnotenia vyžívajú respondenti vo vyučovacom procese. Pri práci s vybranými premennými sme využívali predovšetkým hodnoty modusu a počtu výskytov. 


\section{PREMENNÁ: KRAJ}

Vždy sú využívané nástroje formatívneho hodnotenia 29,4 \% respondentmi v Bratislavskom kraji, iba 9,5 \% respondentmi v Banskobystrickom kraji a 20,0 \% respondentmi v Košickom kraji. Je to pozoruhodný rozdiel, ktorý je predmetom našich d’alších výskumov. Nástroje sumatívneho hodnotenia sú vždy a často využívané $47,0 \%$ respondentmi v Bratislavskom kraji, 45,4 \% respondentmi v Banskobystrickom kraji a 26,9 \% respondentmi v Košickom kraji. Aj ked’ výsledky popisnej štatistiky naznačujú rozdiel v miere používania nástrojov sumatívneho a formatívneho hodnotenia v jednotlivých krajoch, Chí-kvadrát testom tento rozdiel na hladine významnosti $\alpha=0,05$ potvrdený nebol $(p=0,516)$. Môžeme konštatovat, že medzi mierou používania nástrojov sumatívneho a formatívneho hodnotenia nie je signifikantný rozdiel v jednotlivých krajoch (tab. 6).

\section{PREMENNÁ: TYP ŠKOLY}

Nástroje sumatívneho hodnotenia sú učitelmi v ZŠS využívané 34,7 \% vždy a často a učitelmi SS̆ 33,7 \%. Medzi učitelmi jednotlivých škôl sa tak nejavia známky signifikantných rozdielov pri využívaní nástrojov sumatívneho hodnotenia. Nástroje formatívneho hodnotenia sú učitel'mi ZŠ využívané 30,8 \% nikdy a málokedy a učitelmi SS̆ 41,6 \%. Chí-kvadrát testom na hladine významnosti $\alpha=0,05$ bol potvrdený signifikantný rozdiel medzi používaním nástrojov sumatívneho a formatívneho hodnotenia $\mathrm{v}$ prostredí základných škôl $(p=0,031)$. Avšak medzi mierou použivania nástrojov sumatívneho a formatívneho hodnotenia nie je signifikantný rozdiel v typoch škôl (tab. 6).

\section{PREMENNÁ: DĹŽKa PEDAGOGICKEJ PRAXE}

Nástroje sumatívneho hodnotenia využíva vždy a často $50 \%$ respondentov s dížkou pedagogickej praxe 11-15 rokov, 45,5 \% respondentov s dížkou pedagogickej praxe 21-25 rokov a 33,3\% respondentov s dÍžkou pedagogickej praxe 6-10 rokov. Nikdy nevyužíva nástroje formatívneho hodnotenia $25,0 \%$ respondentov s dížkou pedagogickej praxe do 5 rokov, 30,0 \% respondentov s dížkou pedagogickej praxe 11-15 rokov. Chí-kvadrát testom rozdiel na hladine významnosti $\alpha=0,05$ potvrdený nebol ( $p=0,383)$. Môžeme konštatovat, že medzi mierou používania nástrojov sumatívneho a formatívneho hodnotenia nie je signifikantný rozdiel z hladiska dížky pedagogickej praxe učitel'ov (tab. 6).

\section{PREMENNÁ: APROBAČNÝ PREDMET}

V miere využívania nástrojov sumatívneho hodnotenia existujú signifikantné rozdiely na hladine významnosti $\alpha=0,05(p=0,042)$. Najväčší rozdiel je v miere vždy medzi učitel'mi biológie $(17,4 \%)$, učitel'mi iba chémie $(15,8 \%$ ) a učitel'mi geografie $(100,0 \%)$, informatiky (100,0 \%). Nástroje formatívneho hodnotenia nikdy vo vyučovacom procese nevyužíva až 50,0 \% učitelov informatiky, 26,3\% učitelov matematiky a $12,5 \%$ učitelov fyziky. Chí-kvadrát testom rozdiel na hladine významnosti $\alpha=0,05$ potvrdený nebol $(p=0,350)$. Môžeme konštatovat', že medzi mierou používania nástrojov sumatívneho a formatívneho hodnotenia nie je signifikantný rozdiel z hladiska aprobačného predmetu (tab. 6).

Chí-kvadrát test nepotvrdil závislost' využívania nástrojov sumatívneho a formatívneho hodnotenia a vybraných premenných. Miera využívania nástrojov sumatív- 
Tab. 6: Chi-kvadrát test

\begin{tabular}{|c|c|c|c|}
\hline \multirow[b]{2}{*}{ Premenná } & \multicolumn{2}{|c|}{ Nástroje hodnotenia } & \multirow[b]{2}{*}{$\begin{array}{c}\text { Asymp. Sig } \\
\text { (2-sided) }\end{array}$} \\
\hline & $\begin{array}{c}\text { sumatívne } \\
\text { Asymp. Sig. } \\
\text { (2-sided) }\end{array}$ & $\begin{array}{c}\text { formatívne } \\
\text { Asymp. Sig. } \\
\text { (2-sided) }\end{array}$ & \\
\hline Kraj &, 119 & 415 &, 516 \\
\hline $\mathrm{BA}$ & & &, 230 \\
\hline $\mathrm{BB}$ & & &, 624 \\
\hline $\mathrm{KE}$ & & &, 117 \\
\hline Typ školy &, 565 &, 511 &, 287 \\
\hline $\mathrm{ZS}$ & & & ,031 \\
\hline $\mathrm{S} \breve{S}$ & & & ,123 \\
\hline Dížka pedagogickej praxe & ,438 &, 773 &, 383 \\
\hline $0-5$ rokov & & &, 157 \\
\hline $6-10$ rokov & & &, 220 \\
\hline $11-15$ rokov & & &, 356 \\
\hline $16-20$ rokov & & & ,291 \\
\hline $21-25$ rokov & & &, 273 \\
\hline $26-30$ rokov & & &, 238 \\
\hline nad 31 rokov & & &, 241 \\
\hline Aprobačný predmet &, 042 & ,478 &, 350 \\
\hline M & & &, 234 \\
\hline B & & &, 360 \\
\hline $\mathrm{F}$ & & &, 265 \\
\hline $\mathrm{G}$ & & &, 157 \\
\hline $\mathrm{CH}$ & & & ,359 \\
\hline $\mathrm{I}$ & & &, 111 \\
\hline
\end{tabular}

Zdroj: vlastné spracovanie

neho a formatívneho hodnotenia nezávisí od kraja, typu školy, dĺžky pedagogickej praxe, ani aprobačného predmetu. Avšak v miere využívania nástrojov sumatívneho a formatívneho hodnotenia je signifikantný rozdiel. Podla výsledkov popisnej štatistiky stále prevažujú nástroje sumatívneho hodnotenia nad nástrojmi formatívneho hodnotenia vo vyučovacom procese.

\section{Diskusia}

Hodnotenie je neodmyslitelnou súčastou vyučovacieho procesu, poskytuje spätnú väzbu učitelovi, žiakovi i rodičom. Hodnotenie je chápané ako informácia spätnej väzby smerovaná k rozlíšeniu lepšieho od horšieho (Slavík, 1999; Straková \& Slavík, 2013). Žiaka by zároveň malo motivovat k d’alšej činnosti a podporit jeho hodnotenie sveta, no predovšetkým seba samého. Sumatívne a formatívne hodnotenie sa 
zásadne líšia v procese hodnotenia. Kým sumatívne hodnotenie smeruje k hodnoteniu učenia sa, jeho výsledku, formatívne hodnotenie smeruje $\mathrm{k}$ hodnoteniu pre učenie sa, jeho procesu. Formatívne hodnotenie sa v Spojených štátoch amerických využíva vo všetkých vzdelávacích stupňoch a je už zabehnutým hodnotiacim prístupom (OECD, 2013). Výskumy sú zväčša zamerané na skúmanie efektu formatívneho hodnotenia (Newton, 2007; Dunn \& Melvenon, 2009; Ruiz-Primo \& Furtak, 2006). Black et al. (2004) realizovali výskum, v ktorom sledovali dopad využívania formatívneho hodnotenia na zapojených učitelov a ich vztah $\mathrm{k}$ ponímaniu svojej výučby. Učitel' vo vyučovacom procese pracuje prioritne s nástrojmi sumatívneho a formatívneho hodnotenia. Preto sme náš výskum zamerali na zistenie miery využívania nástrojov sumatívneho a formatívneho hodnotenia v praxi učitelov chémie. Vo výskume sme použili výberový súbor tvorený učitel’mi chémie z troch krajov Slovenska. Išlo o učitelov, ktorí z vlastnej iniciatívy využili možnost́ účasti na informačných seminároch zameraných na formatívne hodnotenie. Popisnou štatistikou sme zistili, že v súbore prevažujú jednoznačne ženy, učitel'ky s aprobáciou chémia - biológia a s dĺžkou pedagogickej praxe 16-20 rokov. Táto prevládajúca skupina učiteliek je v produktívnom veku. Pomerne vyvážené bolo rozloženie respondentov v kategóriách 11-15 rokov, 21-25 rokov a nad 31 rokov. Výskumným šetrením sme zistili, že z nástrojov sumatívneho hodnotenia učitelia uprednostňujú testy $(69,2 \%)$, výstupy laboratórnych prác $(67,1 \%)$, slovné odpovede $(64,1 \%)$ a krátke písomné previerky $(53,1 \%)$ pred domácimi úlohami $(45,7 \%)$, výstupmi projektových prác $(45,3 \%)$ a referátmi (11,3\%). Kým nástroje sumatívneho hodnotenia vždy využíva 14,09 \% respondentov, často $36,74 \%$ respondentov, tak nástroje formatívneho hodnotenia využíva vždy iba 5,36 \% respondentov a často $17,15 \%$ respondentov. Pri miere využitia nástrojov formatívneho hodnotenia je opačný posun, nástroje nikdy nevyužíva až 28,04 \% respondentov a málokedy $21,63 \%$ respondentov. Tento rozdiel v miere využívania nástrojov sumatívneho a formatívneho hodnotenia sme štatisticky overili Wilcoxonovým párovým testom, ktorý potvrdil štatisticky významný rozdiel. Black et al. (2004) vo svojom výskume potvrdil, že učitelia, ktorí sami absolvovali vzdelávanie zamerané na formatívne hodnotenie, zmenili charakter svojej výučby smerom $\mathrm{k}$ využívaniu techník formatívneho hodnotenia s dopadom na pozitívne výsledky meratelné sumatívnym hodnotením. V nami realizovanom výskume sa takýto pozitívny dopad štatisticky nepreukázal signifikantný, preto bude predmetom nášho d’alšieho výskumného šetrenia, prečo tento rozdiel nenastal smerom k nástrojom formatívneho hodnotenia a čo ovplyvňuje výber nástrojov hodnotenia učitelom.

Vzhladom na výberovú vzorku výskumného súboru sme zistovali vztahy medzi socio-demografickými premennými a mierou využívania nástrojov formatívneho a sumatívneho hodnotenia. Do vztahu vstupovali štyri premenné: kraj, typ školy, dížka pedagogickej praxe a aprobačný predmet. Výsledky popisnej štatistiky naznačovali rozdiely, avšak štatistická verifikácia pomocou chí-kvadrát testu nepotvrdila štatisticky významné rozdiely. Môžeme konštatovat, že miera využívania nástrojov sumatívneho a formatívneho hodnotenia nezávisí od kraja, z ktorého respondenti pochádzali, ani typu školy, na ktorej pôsobia, ani ich dĺ̌ky pedagogickej praxi a ani aprobačného predmetu.

Výsledky nášho výskumu poukazujú na značné rozdiely vo využívaní nástrojov sumatívneho a formatívneho hodnotenia. Učitelia v značnej miere preferujú nástroje sumatívneho hodnotenia, čo môže byt’ ovplyvnené časovou náročnostou (Novotná \& Krabsová, 2013) a taktiež nejednotnostou terminológie vo vzṫahu ku konkrétnym nástrojom formatívneho hodnotenia (Rokos \& Závodská, 2015). Je potrebné ich brat na zretel' a vytvárat podmienky pre učitelov prírodovedných predmetov, aby 
sa naučili pracovat s nástrojmi predovšetkým formatívneho hodnotenia a efektívne ich využívali vo svojej pedagogickej praxi. Táto možnost by mala byt poskytnutá nielen v rámci kontinuálneho vzdelávania učitelov, ale aj v pregraduálnej príprave, ako tomu nasvedčujú výsledky výskumu medzi študentmi vysokých škôl (Rokos \& Závodská, 2015).

\section{ZÁVER}

Pokles prírodovednej gramotnosti žiakov základných škôl a stredných odborných škôl bez maturity je impulzom pre učitelov prírodovedných predmetov, aby v rámci svojich možností prispeli k eliminácii tohto nežiadúceho stavu. Výskumy naznačujú, že možnostou je využívanie formatívneho hodnotenia vo vyučovacom procese, ktoré podporuje rozvoj osobnosti žiaka v oblasti poznania a správania sa. Čiastkové výsledky nášho výskumu poukazujú na rozdiely využívania nástrojov sumatívneho a formatívneho hodnotenia učitel’mi. Učitelia $\mathrm{v}$ značnej miere preferujú nástroje sumatívneho hodnotenia nad nástrojmi formatívneho hodnotenia. Je dôležité zamysliet sa nad dôvodmi ich konania. Je to neznalost, obava z nepoznaného, strata času z vyučovacej jednotky, či nerešpektovanie komplexnej transformácie vzdelávania za ostatných 25 rokov na Slovensku? Pri doteraz realizovaných zmenách v rámci školských reforiem sa dôraz kládol na zmeny obsahu, metód, prostriedkov vo vyučovacom procese, no málo pozornosti bolo venovanej práve zmenám stratégií vo výučbe a v hodnotení, predovšetkým formatívnom hodnotení procesu učenia sa žiakov. To môže byt i klúčovým dôvodom zníženého záujmu o nástroje formatívneho hodnotenia zo strany učitelov. Eliminovat tento stav vo vztahu k učitelom prírodovedných predmetov je možné prípravou praktických školení pre učitelov na tému formatívneho hodnotenia $\mathrm{v}$ ich vyučovacom predmete a implementáciou formatívneho hodnotenia do pregraduálnej prípravy študentov prírodovedných predmetov.

\section{OBMEDZENIA VÝSKUMU}

Do výskumného šetrenia boli zámerným výberom zapojení učitelia chémie v kombinácii, ktorí boli účastníkmi praktických školení s témou formatívneho hodnotenia. Predpokladali sme, že títo respondenti terminologicky ovládajú predmetnú problematiku a dokážu relevantne odlíšit nástroje formatívneho a sumatívneho hodnotenia. Uvedomujeme si však, že výsledky prezentované v tejto štúdii, vo vztahu k vel'kosti výskumnej vzorky, nie sú v plnej miere zovšeobecnitelné. Ale je možné s nimi pracovat pri tvorbe výskumných nástrojov pre d’alšie výskumné šetrenia formatívneho hodnotenia vo vyučovacom procese.

\section{POĎAKOVANIE}

Článok bol realizovaný za podpory projektu VEGA 1/0265/17 Formatívne hodnotenie vo výučbe prírodných vied, matematiky a informatiky.

\section{LITERATURA}

Black, P., Harrison, C., Lee, C., Marshall, B. \& Wiliam, D. (2004). Working inside the black box: Assessment for learning in the classroom. Phi Delta Kappan, 86(1), 8-21. DOI: $10.1177 / 003172170408600105$ 
Black, P. \& Wiliam, D. (1998). Inside the black box. Raising standards through classroom assessment. Phi Delta Kappan, 80(2), 139-148.

Black, P. \& Wiliam, D. (2003). Praise of educational research: Formative assessment. British Educational Research Journal, 29(5), 623-637.

DOI: $10.1080 / 0141192032000133721$

Čapek, R. (2015). Moderni didaktika. Lexikon výukových a hodnoticích metod. 1. vydanie. Praha: Grada Publishing.

Dunn, K. E. \& Mulvenon, S. W. (2009). A critical review of research on formative assessments: The limited scientific evidence of the impact of formative assessments in education. Practical Assessment 85 Research and Evaluation, 14(7), 1-11.

Earl, L. \& Katz, S. (2006). Rethinking classroom assessment with purpose. Education and advanced learning-assessment and evaluation. Dostupné na http://www.edu.gov.mb.ca/k12/assess/wncp/full_doc.pdf [cit. 6. 2. 2014]

Earle, S. (2014). Formative and summative assessment of science in English primary schools: evidence from the Primary Science Quality Mark. Research in Science $\&$ Technological Education, 32(2), 216-228.

Flavell, J.H. (1979). Metacognition and cognitive monitoring: A new area of cognitive-developmental inquiry. American Psychologist, 34(10), 906-911.

Grob, R., Holmeier, M. \& Labudde, P. (2017). Formative assessment to support students' competences in inquiry-based science education. Interdisciplinary Journal of Problem-Based Learning, 11(2). http://dx.doi.org/10.7771/1541-5015.1673

Holt, J. (1991). Az iskola kudarcai. Budapest: Gondolat Könyvkiadó.

Januševa, V. \& Jurukovska, J. (2017). Formative assessment in teaching the Macedonian language. International Journal of Assessment Tools in Education, 4(1), 54-78.

DOI: $10.21449 /$ ijate.266059

Kalhoust, Z. \& Obst, O., et al. (2002). Školní didaktika. Praha: Portál.

Kolář, Z. \& Šikulová, R. (2009). Hodnocení žáků. Praha: Grada Publishing.

Kosová, B. (2000). Hodnotenie ako prostriedok humanizácie. Prešov: MPC.

Kyriacou, CH. (2012). Klíčové dovednosti učitele. Praha: Portál.

Mešková, M. (2012). Motivace žáků efektivní komunikací. Praha: Portál.

Newton, P. E. (2007). Clarifying the purposes of educational assessment. Assessment in Education: Principles, Policy \& Practice, 14(2), 149-170.

DOI: $10.1080 / 09695940701478321$

Novotná, K. \& Krabsová, V. (2013). Formativní hodnocení: př́ípadová studie. Pedagogika, 63(3), 355-371.

NUCEM. (2017). Národná správa PISA 2015. (1-87). Dostupné na http://www.nucem.sk/documents//27//NS_PISA_2015.pdf [cit. 14. 6. 2018]

OECD. (2013). Reviews of evaluation and assessment in education - synergies for better learning: An international perspective on evaluation and assessment. OECD Publishing.

Průcha, J. (1997). Moderní pedagogika. Praha: Portál.

Rokos, L. \& Závodská, R. (2015). Formative assessment and other assessment methods in biology education and pre-service biology teacher training in the Czech Republic. 
International Journal of Assessment and Evaluation, 23(2), 17-27. https://doi.org/10.18848/2327-7920/CGP/v23i02/48388

Ruiz-Primo, M. A. \& Furtak, E. M. (2006). Exploring teachers' informal formative assessment practices and students' understanding in the context of scientific inquiry. Journal of Research in Science Teaching, 44(1), 57-84. DOI: 10.1002/tea.20163

Scriven, M. (1967). The methodology of evaluation. Washington, DC: American Educational Research Association.

Slavík, J. (1999). Hodnocení v současné škole. Praha: Portál.

Starý, K. \& Laufková, V., et al. (2016). Formativní hodnocení ve výuce. Praha: Portál.

Straková, J. \& Slavík, J. (2013). (Formativní) hodnocení - aktuální téma. Pedagogika, $53(3), 277-284$.

Szarka, K. (2017). Súčasné trendy školského hodnotenia: Koncepcia rozvíjajúceho hodnotenia. Komárno: KOMPRESS.

Torrance, H. \& Pryor, J. (2001). Developing formative assessment in the classroom: Using action research to explore and modify theory. British Educational Research Journal, 27(5), 615-631. https://doi.org/10.1080/01411920120095780

Turek, I. (2014). Didaktika. Bratislava: Wolters Kluwer.

RENÁTA ORosovÁ, renata.orosova@upjs.sk

UPJŠS, Filozofická fakulta

Katedra pedagogiky

Moyzesova 9, 04001 Košice, Slovenská republika

MÁRIA GANAJOVÁ, maria.ganajova@upjs.sk

MÁRIA BABINČÁKOVÁ, maria.babincakova@upjs.sk

UPJŠ, Prírodovedecká fakulta

Oddelenie didaktiky chémie, Ústav chemických vied

Moyzesova 11, 04001 Košice, Slovenská republika

KATARÍnA SzARKA, szarkak@ujs.sk

UJS, Pedagogická fakulta

Katedra chémie

Bratislavská 3322, 94501 Komárno, Slovenská republika 